\title{
A ROMAN REPUBLICAN OPENWORK BELT PLATE FROM A SANCTUARY GURZUFSKOE SEDLO: THE PARALLELS TO CASTILLEJO FINDS
}

\begin{abstract}
A paper is devoted to a rare find of a Roman bronze openwork belt plate with the preserved skin residues found in a mountain sanctuary Gurzufskoe Sedlo together with the items of the Roman military equipment principally dated by the Late Republican - Early Principate periods. It's finding in a barbarian sanctuary along with the items of Roman Republican equipment is associated with the participation of Tauri tribes in the military actions against Rome in the Black Sea region during the first half of a 1st century BC. It is possible to study the features of the construction and decor elements of an item due to a good state of its preserve.

Keywords: Roman Republican and Late La Téne equipment, military suite, belt plate, mountain sanctuary, armour votive offerings, $2^{\text {nd }}-1^{\text {st }}$ centuries $B C$, Mountain Taurica, sanctuary Gurzufskoe Sedlo, Tauri population.
\end{abstract}

$\mathbf{T}$ he sanctuary near the pass Gurzufskoe Sedlo was opened in 1981on the Southwest plain of the Main Ridge of the Crimean Mountains on Kalfrakh-Kayasi mount, Southern Taurica on the height of $1434 \mathrm{~m}$ above the sea level (Fig. 1/1-2). ${ }^{1}$ The excavations were carried out by archaeological expedition of Yalta Historical and Literary Museum under the guidance of N. G. Novichenkova and V. I. Novichenkov in 1981-1993. Cultural accumulations of an Antique époque were represented by the strata of the Hellenistic period (the $4^{\text {th }}$ - the 30 -ies of the $1^{\text {st }}$ centuries BC) and strata of the last quarter of the $1^{\text {st }}$ century $\mathrm{BC}$ - the $3^{\text {rd }}$ century AD. ${ }^{2}$ Hellenistic strata consisted the mass gathering of jaws of large and small cattle. The strata of the Roman period consisted of high content of ash inclusions and fragmented burned bones of animals, smelted metal, and glass. The heyday of the functioning of the sanctuary belongs to the last quarter of $1^{\text {st }}$ century $B C$ - the first half of the $1^{\text {st }}$ century AD when the new ritual complex with an arcuate line of sacrificial pits with usage of burning ceremonies in cult practices was created. ${ }^{3}$ The soil and climatic features of the highlands determined the good preservation of metal and glass finds. Due to the lack of looting of the sanctuary in ancient times, there were revealed a high saturation of votive offerings at cultural layers of a site. Items associated with Roman Republican armor were revealed in Hellenistic strata as well as in layers of the Roman

\footnotetext{
NOVICHENKOVA 2002; NOVICHENKOVA 2015.

2 NOVICHENKOVA 2002, 135, 145-146; NOVICHENKOVA 2015, 117-121.

${ }^{3}$ NOVICHENKOVA 2002, 47; NOVICHENKOVA 2015, 121.
}

\section{Maria V. NOVICHENKOVA}

Institute of Archaeology,

National Academy of Sciences of Ukraine, novichenkovamaria@gmail.com 
period. Some of them were presumably re-depozited and / or re-donated in a later period.

At strata of the Roman period was found the bronze openworked rectangular belt detail revealed together with the iron loop spur presumably of the Hellenistic period, ${ }^{4}$ the upper part of the Hellenistic cast polychrome rhyto, ${ }^{5}$ a coreformed alabastron head, the Roman silver button-and-loop cingulum fastener with the triangular frame, with a terminal in the form of a flattened rod, and the silver pendant with a polychrome glass intaglio with the depiction of a horse rider with an oval shield and spears. The belt detail ${ }^{6}$ consists of two rectangular plates joined by four dome-headed rivets with decorated massive nail-heads in the corners (Fig. 2). The upper plate has a carved floral ornament presented by repeating tracery of four petals with miniature nails in centers. The fragmented leather insert preserved under the upper plate had the stamped rhomboid ornament. The interior plate has a point-wave frame ornament on the edges. In the central part the interior plate has a rectangular protrusion. The dimensions of a plate: $\mathrm{H}=4,3 \mathrm{~cm}, \mathrm{~W}=$ $5,1 \mathrm{~cm}$, the thickness $=0,8 \mathrm{~cm}, \varnothing$ of the nail-heads $=1,0 \mathrm{x} 0,9$, 0,9, 0,9, 0,8x0,9 cm. Passport data: ГС-83, ко 1420, sq. 10Л, dark strata with ash and burned bones, Yalta Historical and Literary museum, museum number КП 31685, А3 864. Since the belt plate was found in a layer of a Roman period together with some Hellenistic items it can be dated only by the analogies. The bronze rectangular openworked belt plates jointed with four nail-heads are known by finds from Roman military camp Castillejo (Numantia); some of them had also the preserved inserts of the embossed leather with the identical rhomboid ornament. ${ }^{7}$ The Castillejo buckle and one of the belt plates have the same preserved rectangular protrusions, the buckle has the wave ornament and the nailheads with a similar crossing ornament, the $\mathrm{H}$ of the items is $4,1-4,2 \mathrm{~cm}^{8}$. The dimensions of one of the entire Castillejo belt-plate are $4 \times 4,5 \mathrm{~cm}^{9}$. The belt plate from Gurzufskoe Sedlo can also be dated by its separate elements: the decorated nailheads are of a rare type, of a Celtic origin, known by the finds from oppidum Manching, South Gaulish Saone-et-Loire, dated by the context of finds from Gaulish sites by 120-30 $\mathrm{BC} .{ }^{10}$ Decorated hob-nails with the relief line ornament have the helmets of Western Celtic or Alesia type, known by the exemplars from BOẺ, Agen, ${ }^{11}$ Alesia ${ }^{12}$, Gubiasco, Besançon, dated by $60-40^{\text {th }}$ of the $1^{\text {st }}$ century $\mathrm{BC}$. $^{13}$ The belt plate from Gurzufskoe Sedlo can be dated by analogies by the end of the $2^{\text {nd }}$ - the first half of the $1^{\text {st }}$ centuries BC.

Little is known about the types of military belts in a uniform of a Roman Republican army. There are also known the several belt plates from Renieblas camp III, Castillejo,

\footnotetext{
${ }^{4}$ NOVIČENKOVA/KONTNY 2015, 305-306, Fig. 3/1.

${ }^{5}$ NOVICHENKOVA-LUKICHEVA 2010, 321-325.

NOVICHENKOVA 1998, Fig. 12-1; NOVICHENKOVA 2002; NOVICHENKOVA 2015.

LUIK 2002, 256, Abb. 79, cat. no. C 59-61; BISHOP/COULSTON 2006, 67 Fig. 33/3.

8 LUIK 2002, Abb. 79, cat. no. C 58-59.

9 BISHOP/COULSTON 2006, 67.

10 DÉCHELETTE 1914, 971, Fig. 404; VON ENDERT 1991, Pl. 37, no. 608 , 610, 612, 615, 620; CHALLET 1992, Fig. 76.

11 SCHÖNFELDER 2000, 143, Fig. 38.

12 SIEVERS/BROUQUIER REDDÉ/DEYBER 2001, Pl. 42/16, 17, 21-24.

${ }^{13}$ FEUGÉRE 2013, 22, Fig. 1, 2.
}

Cáceres-el-Viejo sites. Besides the single archaeological finds of belt parts the information about it presents the images of lapidary sources depicted on the monument of Aemilius Paullus, the Altar of Domitius Ahenobarbus. ${ }^{14}$

At cultural strata of the barbarian sanctuary Gurzufskoe Sedlo were found the numerous pieces of details of Roman military equipment of the $2^{\text {nd }}$ century $\mathrm{BC}$ - the $3^{\text {rd }}$ century AD representing the main types of Roman offensive, defensive armor, cavalry equipment, military suite, objects of the military cult and insignia and camp life. ${ }^{15}$ The majority of items of Roman military equipment date back to the reign of Augustus and a boundary era. ${ }^{16}$ The most part of Roman armor was ritually damaged, cut on pieces. There are allocated among the finds two the earliest chronological groups appurtenant to the Roman Republican armor ${ }^{17}$.

The first group dated by the $2^{\text {nd }}$ - the first half of the $1^{\text {st }}$ centuries BC (group 1 ) is presented by the javelin heads, the parts of helmets - the Etrusco-Italic Montefortinotype helmets, details of an oval Scutum shield ${ }^{18}$, a detail of a military signum ${ }^{19}$, horse harness buckles. This dating has the most part of La Tène metal ware, La Tène military equipment - the offensive weapons, belt-set parts, horse gear (pendants, phalerae, strap-ends), spurs, close in most to finds from archaeological sites of Gaul, the bronze cast parts of Hellenistic kline / lectus, the elements of Hellenistic armor, the statuettes of deities of the Graeco-Roman pantheon, the several medical theca vulneraria tubes, more than a thirty of cast glass vessels. The numismatic group of this period is presented by Roman Republican coins dated by the period of the Mithridatic Wars of 89-85, 83-81 and 74-63 BC, including a denarius of military moving mint of L. Cornelius Sulla and L. Manlius Torquatus of 82 BC $^{20}$ (Fig. 1/3), the coins of Pontus belong to the reign of Mithridates VI Eupator ${ }^{21}$. Most of the bulk of items of the first chronological group of Roman military equipment from the sanctuary can be associated with the era of Mithridatic Wars and serve as an indicator of the military and political activity of the local population of the Mountain Taurica in events in Pontic region at the first half of the $1^{\text {st }}$ century $B C$, its involvement on the side of Mithridates VI Eupator, King of Pontus in the Wars. Numismatic sources confirm that the Southern Taurica during the establishment of the Roman political influence in Black Sea Coast in this period was in a sphere of power of the Kingdom of Pontus.

The Roman Republican equipment of the $50^{\text {th }}-$ the $30^{\text {th }}$ of the $1^{\text {st }}$ century BC - of an era of Julius Caesar dictatorship and Octavianus rule (group 2) is presented by a cheek-piece of helmet of the West Celtic type, ${ }^{22}$ catapult bolts, pyramidal arrow heads, belt triangular button-and-loop fasteners, Alesia fibulae $^{23}$ correlated with the dating of Roman Late Republican

\footnotetext{
4 BISHOP/COULSTON 2006, 67.

15 NOVICHENKOVA 1998, 51-66; NOVICHENKOVA 2011, 271-297; NOVICHENKOVA 2017.

${ }^{16}$ NOVICHENKOVA 1998, 51-52.

17 The material is preparing to a publication.

18 NOVICHENKOVA 2015a, 321-327.

19 NOVICHENKOVA 2016, 219-222.

${ }^{20}$ CRAWFORD 1974, 367/5, SYDENHAM 1952, 757

1 NOVICHENKOVA 2015, 49-53.

22 NOVICHENKOVA 2013, 311-313.

${ }^{23}$ NOVICHENKOVA 2000, 160, Fig. 5/1-6.
} 
coins from the sanctuary - of the First Triumvirate of 6055 BC, the Civil War of the 49-45 BC including the six denarii of Julius Caesar, of the Second Triumvirate. Late Republican military equipment items from the sanctuary Gurzufskoe Sedlo have the close features with military equipment complexes of Gaulish sites, is presented by details of ammunition general for finds from Gaulish oppida of time of their gaining by Rome and the basis in these territories of the first Roman camps including Bibracte, Alesia, Gergovie.

Historically, a Mountain Crimea by an antique written sources determine to a region Taurica inhabited by Tauri tribes. Herodotus describes the type of the Tauri customs, including their tradition of sacrificing: "all shipwrecked men, and any Greeks whom they capture in their searaids, they sacrifice to the Virgin goddess...The Tauri live by plundering and war.." ${ }^{24}$. Strabo determined the Tauri, as a Scythian tribe ${ }^{25}$. Pliny the Elder wrote about the Scythotauri who "...occupy the ...ridge "26 - a Main ridge of the Crimean Mountains where a sanctuary Gurzufskoe Sedlo is situated. It is known in written sources about the participation of inhabitants of Mountain Taurica in the Mithridatic Wars as an allies of the Mithridates VI Eupator "...He [Mithridates VI] has allies also ready to obey his every command, Scythians, Taurians, Bastarnae, Thracians, Sarmatians..."27, "...he had for allies the Chalybes, Armenians, Scythians, Taurians..."

Chronological group of Roman Republican armour of $50-30^{\text {th }} \mathrm{BC}$ had reflected the political and military activity of Roman state in the East at this period. There were the Eastern campaign of Marcus Licinius Crassus of 55-53 BC ${ }^{29}$, Roman defeat at Battle of Nicopolis in 48 BC caused the Caesar War in Pontus ended with the Battle of Zela in 47 $\mathrm{BC}$ with Pharnaces II, the King of Pontus and the Bosporan Kingdom during the reign of Julius Caesar, an unsuccessful Parthian military campaign of Marcus Antonius in 40-33 $\mathrm{BC}^{30}$. The political and military participation of barbarous elite in the events of $50^{\text {th }}$ - the last quarter of $1^{\text {st }}$ century BC took place possibly supporting the Bosporus: the Pharnace II, later the Asander, whose board was forwarded to conduct an independent policy from Rome ${ }^{31}$. The most probable is observing of Roman Republican military equipment items from Gurzufskoe Sedlo as a military booty and the naval way of it penetrating. By archaeological data the mountain Tauri population stayed in constant opposition to Roman military forces since the beginning of Roman military and political influence in Black Sea region in $2^{\text {nd }}$ century BC and took an active part in military actions against Rome for the next several centuries.

\section{REFERENCES}

BISHOP/COULSTON 2006

Bishop, M. C., Coulston, J. C. N., Roman Military Equipment from the Punic Wars to the Fall of Rome, $2^{\text {nd }}$ ed. (Oxford : Oxbow).

\footnotetext{
${ }^{24}$ HERODOTUS IV, 103.1, 3.

25 STRABO VII, 4.2.

26 PLINIUS IV, 26.

27 APPIAN, Mithridates, 15.

${ }^{28}$ APPIAN, Mithridates, 69

29 CASSIUS DIO XL, 4, 24.

30 PLUTARCH, Antonius, 50, 51.

31 APPIAN, Mithridates, 120, 121; STRABO XIII. 4, 3.
}

\section{CHALLET 1992}

Challet, V., Les Celtes et l'émail (Paris: Editions du Comité des Travaux historiques et scientifiques).

CRAWFORD 1974

Crawford, M. H., Roman Republican Coinage. Vol. I-II (Cambridge).

DÉCHELETTE 1914

Déchelette, J., Manuel d'archéologie préhistorique, celtique et gallo-romaine, II. Archéologie celtique et protohistorique, Second Age du Fer ou époque de La Tène (Paris: A. Picard).

\section{FEUGÉRE 2013}

Feugère, M., Le casque gaulois de Besançon (F, Doubs), Instrumentum 38, 18-23.

\section{LUIK 2002}

Luik, M., Die Funde aus den römischen Lagern um Numantia im Römisch-Germanischen Zentralmuseum. [Katalogue vorund frühgeschichtlicher Altertümer 31] (Mainz: Verlag des Römisch-Germanischen Zentralmuseums in Kommission bei Dr. Rudolf Habelt Gmbh, Bonn).

\section{NOVICHENKOVA 1998}

Novichenkova, N. G., Rimskoe voennoe snaryazhenie is svyatilishcha u perevala Gurzufskoe Sedlo, Vestnik Drevnei Istorii 2, 51-66.

\section{NOVICHENKOVA 2000}

Novichenkova, N. G., Fibuli iz svyatilishcha u perevala Gurzufskoe Sedlo, Rossiyskaya arkheologiya 1, 154-166.

\section{NOVICHENKOVA 2002}

Novichenkova, N. G., Ustroystvo i obryadnost' svyatilishcha u perevala Gurzufskoe Sedlo (Yalta: RIO KGGI).

\section{NOVICHENKOVA 2011}

Novichenkova, M. V., Rimskaya kol'chyuga Lorica Hamata I v. do n.e. - I v. n.e. iz ritual'nogo kompleksa svatyilishcha Gurzufskoe Sedlo, Bosporskie isssledovaniya 25, 271-297.

NOVICHENKOVA 2013

Novichenkova, M. V., K nakhodkam dvukh nacshechnikov shlemov iz svatyilishcha y perevala Gurzufskoe Sedlo. In: Shestaya Mezhdunarodnaya Kubanskaya arkheologicheskaya konferentsiya: Materialy konferentsii (Krasnodar), 311-313.

NOVICHENKOVA 2015

Novichenkova, N. G., Gornyi Krym: II v. do n.e. - II v. n.e. Po materialam raskopok svyatilishcha u perevala Gurzufskoe Sedlo (Simferopol).

NOVICHENKOVA 2015a

Novichenkova, M. V., Detali rimskogo shchita Scutum pozdnerespublikanskogo vremeni iz Gornogo Kryima. In: OLBIO. In memoriam V. V. Krapivina (Kyiv), 321-327.

NOVICHENKOVA 2016

Novichenkova, M., Detail of Roman Late Republican signum from a sanctuary Gurzufskoe Sedlo, Journal of Roman Military Equipment Studies 17, 219-222.

NOVICHENKOVA 2017

Novichenkova, M. V., Rimske viyskove sporyadzhennya $v$ Tavrici I st. do n.e. - I st. n.e. (za materialami rozkopok svyatilishcha Gurzufske Sidlo). Avtoreferat dissertacii (Kyiv, Institut arkheologii Natsional'noi akademii nauk Ukraini).

\section{NOVIČENKOVA/KONTNY 2015}

Novičenkova, M./Kontny, B., Spurs from the Sanctuary at the Gurzufskoe Sedlo. On the Problem of Hook Spurs. In: A. Tomas (ed.), Ad fines Imperii Romani. Studia Thaddaeo Sarnowski septuagenario ab amicis, collegis discipulisque dedicate (Warzsawa: Institute of Archaeology Warsaw University), 303-324.

\section{NOVICHENKOVA-LUKICHEVA 2010}

Novichenkova-Lukicheva, K. V., Tri steklyannikh polikhromnikh ritona ellinisticheskogo vremeni is svyatilishcha Yuzhnoj Tavriki, Bosporskie isssledovaniya 23, 321-325. 


\section{NOVICHENKOVA/NOVICHENKOVA 2017}

Novichenkova, N. G./Novichenkova, M. V., Roman Republican and Provincial Coins from the Archaeological Excavations of the Sanctuary near the pass Gurzufskoe Sedlo in the Crimean Mountains. In: Krym i pótnocne wybrzeża Morza Czarnego $w$ badaniach archeologicznych 1956-2013 (Warszawa: Instytut Archeologii UW), 223-236. SIEVERS/BROUQUIER REDDÉ/DEYBER 2001

Sievers, S./Brouquier Reddé, V./Deyber, A., Les armes d'Alésia. In: Reddé, M./Von Schnurbein. (eds.), Alésia: fouilles et recherches franco-allemandes sur les travaux militaires romains autour du Mont-Auxois (1991-1997), vol. II: Le materiel [Mémoires de l'Institut de France, Académie des Inscriptions et Belles-Lettres, T 22] (Paris: Boccard).

\section{SCHÖNFELDER 2000}

Schönfelder, M., Le mobilier métallique de la tombe à char tardo-celtique de Boé (Lot-et-Garonne), Aquitania 17, 59-81. SYDENHAM 1952

Sydenham, E. A., The Coinage of the Roman Republic (London)..

\section{VON ENDERT 1991}

von Endert, D., Die Bronzefunde aus dem Oppidum von Manching. Kommentierter Katalog. [Die Ausgrabungen in Manching 13] (Stuttgart: Stuttgart Steiner).

\section{Written sources}

APPIAN, Roman History, vol. I-IV, Translated by Horace White, Loeb Classical Library (1912-1913).

DIO CASSIUS, Roman History, vol. I-IX, Translated by Earnest Cary, on the basis of the version of Herbert Baldwin Foster, Loeb Classical Library (1914-1927).

HERODOTUS, The Histories, vol. I-IV, Translated by A. D. Godley, Loeb Classical Library (1920-1925).

PLINY, Natural History, vol. I-X, Translated by H. Rackham (vol. 1-5, 9), David Edward Eichholz; (vol. 6-8), William Henry Samuel Jones (vol. 10), Loeb Classical Library (1938-1962).

PLUTARCH, Lives, vol. I-IX, Translated by Bernadotte Perrin, Loeb Classical Library (1914-1920).

STRABO, Geography, vol. I-VIII, Translated by Horace Leonard Jones, Loeb Classical Library (1917-1932). 

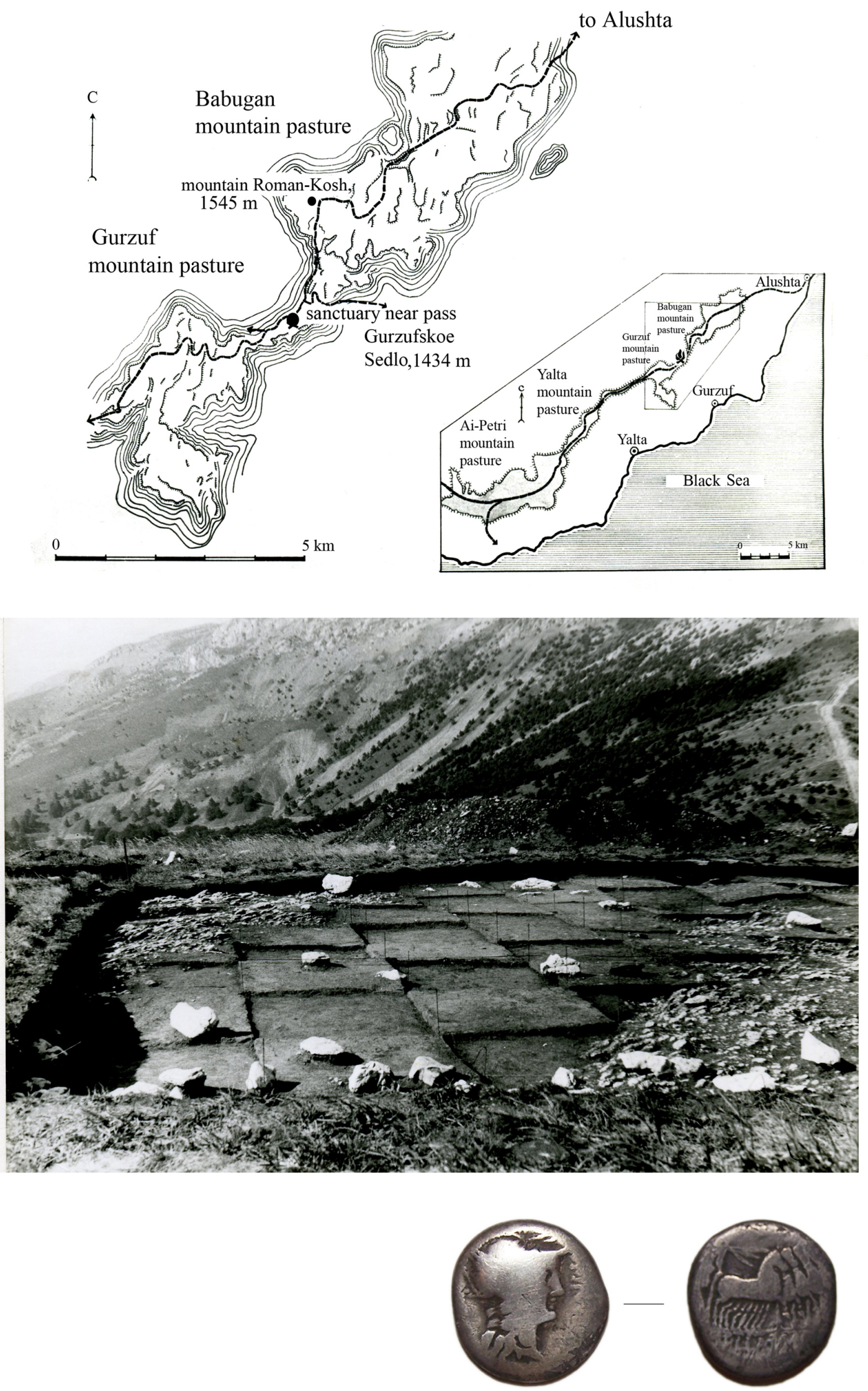

Fig. 1. Sanctuary near the pass Gurzufskoe Sedlo. 1. The map (after NOVICHENKOVA 2002, Fig. 4)

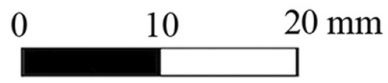

2. Excavations of a site in 1983 (after NOVICHENKOVA 2015, Fig. 51).

3. Roman Republican denarius of L. Cornelius Sulla and L. Manlius

Torquatus of $82 \mathrm{BC}$ of a military moving mint (after NOVICHENKOVA/ NOVICHENKOVA 2017, Pl. 1/6). 

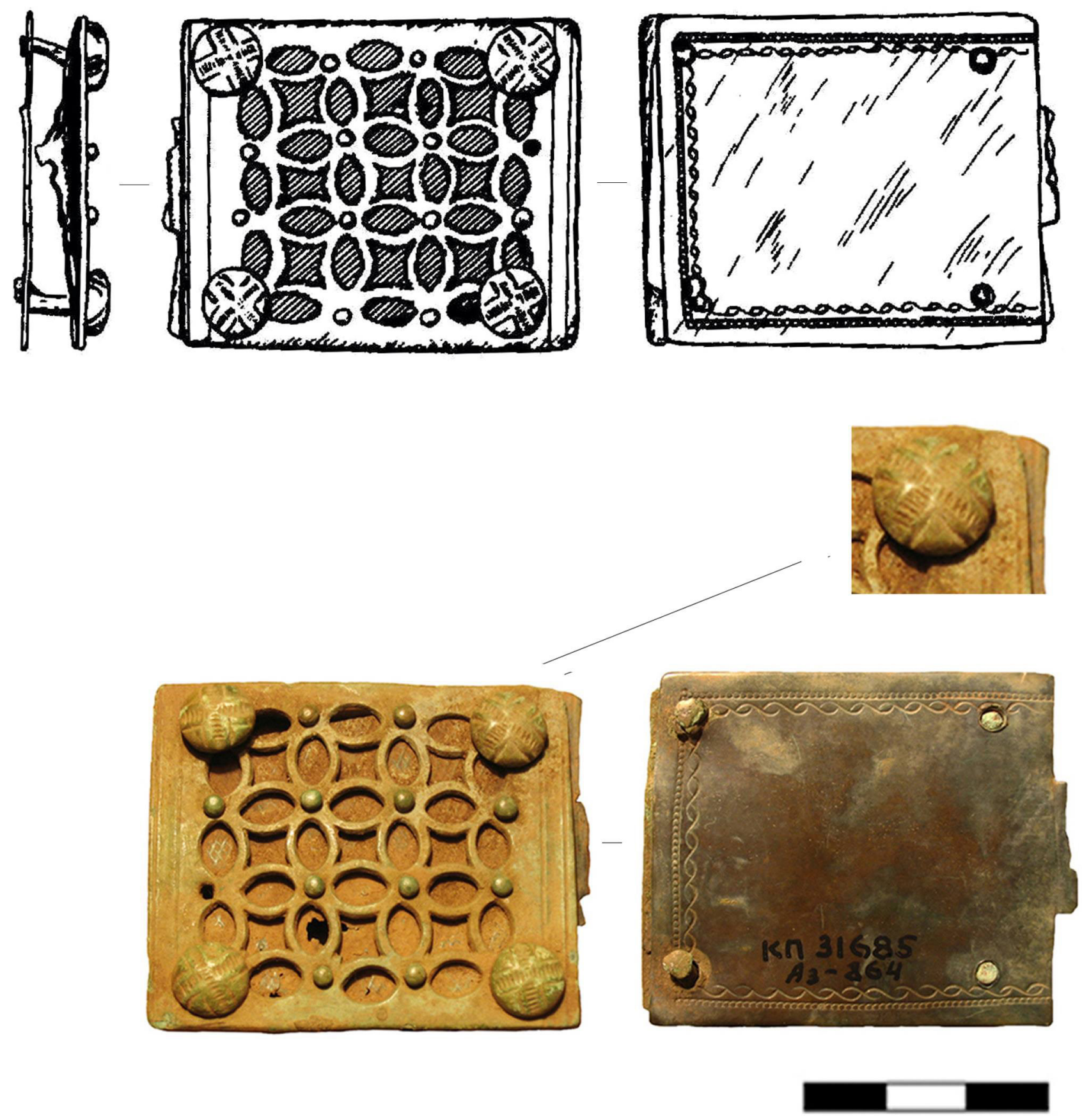

Fig. 2. Bronze openwork belt plate with leather insert from a sanctuary near the pass Gurzufskoe Sedlo (after NOVICHENKOVA 2015, Fig. 98/1, 101, 102). 